\title{
LABOR HOARDING: AN OLD PHENOMENA IN MODERN TIMES? CASE STUDY FOR EU COUNTRIES
}

\author{
Kamila RADLIŃSKA (D) ${ }^{1}$, Maria KLONOWSKA-MATYNIA (D)1, \\ Agnieszka JAKUBOWSKA (D) ${ }^{1}$, Grzegorz KWIATKOWSKI (D) 1, 2* \\ ${ }^{1}$ Faculty of Economics Sciences, Koszalin University of Technology, Koszalin, Poland \\ ${ }^{2}$ Faculty of Business Administration and Social Sciences, \\ Western Norway University of Applied Sciences, Bergen, Norway
}

Received 08 July 2019; accepted 10 February 2020

\begin{abstract}
A consequence of similar institutional conditions of domestic labor markets in Europe is the permanent occurrence of the "labor hoarding" phenomenon, which entails non-immediate adaptation of employment to production changes. The article verifies whether the phenomenon of labor hoarding occurs in the European Union countries and what is its level and the direction of changes between 1996 and 2016. The empirical study of employment adjustments to the production volume showed that in the examined period the phenomenon of labor hoarding occurred in all countries of the European Union (excluding Spain). Labor hoarding was accomplished through a slight adjustment of the number of employees to production changes. At the same time, it was noticed that the companies were more flexible with adjusting the number of hours worked. This was particularly evident during global crises and was the consequence of other vital changes in national economies.
\end{abstract}

Keywords: productivity, business cycle, labor hoarding, changes, European Union countries, global crises.

JEL Classification: J23, E32.

\section{Introduction}

The issue of managing human resources is often taken up in the literature. Analyses at the company level focus on the methods of obtaining employees (Cassell et al., 2002; Day \& Rodgers, 2015; Dawson et al., 2017), determining salary level (Card et al., 2016; Lopes de Melo, 2018), assessing the impact of technological progress on the structure of employment in companies (Arntz et al., 2016; Frey \& Osborne, 2017; Olkiewicz, 2015). In macroeconomic terms, the most frequently discussed issues concern the flexibility of working time (Wilthagen \&

\footnotetext{
*Corresponding author. E-mail: gregory.kwiatkowski@hvl.no
} 
Tros, 2004; Chen et al., 2019), the minimum wage (Blanchard, 2004), labor market equilibrium (Blanchard \& Landier, 2002; Gałecka-Burdziak, 2017) and work productivity (Boeri \& Garibaldi, 2005a; Nitoi \& Pochea, 2016; Stone, 1923; Quiggin, 2011; Klinger \& Weber, 2019). The functioning of labor market, both in the micro- and macroeconomic context, depends on the solutions used in labor market institutions (Jiménez-Rodríguez \& Russo, 2012; Boeri, 2011). Regulations regarding, among others, hiring new employees, laying off current employees, shaping working hours and instruments of labor market policies are of paramount importance in the reaction of labor markets to changes in economic activity.

From the point of view of economic practice and labor market policy, it seems particularly interesting to study the use of labor resources in the business cycle. Labor market rigidity, in particular excessive protection of employment and high tax wedge make it difficult to adapt labor resources to changes in production in companies. As a consequence, the economy's response to changed conditions is delayed. One of the concepts of optimization of company decisions on human resources management in the conditions of economic slowdown is labor hoarding (Barth et al., 2017; Biddle, 2015; Burnside et al., 1993; Hart, 2019; Vella, 2018). This phenomenon is based on an non-immediate adaptation of employment to changes in production volume. As a result, during economic stagnation, employment decreases more slowly than production volume, and in periods of economic growth employment is increasing more slowly (than production volume). Such an employment adjustment mechanism results from companies decisions whose aim is to maximize profits in the long term. As the costs of redundancies, re-employment and training may exceed the costs of employee retention in the conditions of short-term production decline, enterprises will not (in a short period of time) adjust employment (Ehrenberg \& Smith, 2012; Pissarides, 1991; Strzelecki et al., 2009). In addition, institutional determinants of the labor market may strongly affect the speed of matching employment to production changes (Burda et al., 2019). The speed of adjustments may result from labor market regulations regarding the flexibility of labor relations, securing jobs or reducing the bargaining power of trade unions (Mangan, 1982; Barth et al., 2017; Bentolila \& Dolado, 1994; Dietz et al., 2010). A restrictive labor market negatively affects labor productivity (Tressel \& Scarpetta, 2004) - reduces the rate of job creation and the rate of job liquidation (Jiménez-Rodríguez \& Russo, 2012), extends the duration of unemployment and makes it difficult for people in strenuous labor market situations to take up employment, e.g. women, young people or immigrants.

Identification of labor hoarding phenomenon can be made on the basis of macroeconomic data, by analyzing the dynamics of production and labor productivity. This method is relatively simple to perform, and its assumptions have a strong theoretical grounding. An alternative method of measurement is to conduct analyses based on unit data.

Countries of the European Union are particularly vulnerable to the phenomenon of labor hoarding, its level is higher than in the American economy (Pissarides, 1991). The functioning conditions of national labor markets determine the strength of adjusting labor to changes in production volume. In the countries of the Eastern and Central European bloc, the phenomenon of labor hoarding was high in the initial phase of political transformation, but its severity was treated as a temporary effect of systemic changes, and currently it does not deviate from the moderate European Union level (Strzelecki et al., 2009; Radlińska, 
2018). Considerable hoarding of labor is also observed in the economies of Germany, France, Great Britain, and it is the result of employment protection used by the governments of these countries, and of well-functioning and flexible forms of employment and subsidizing of work, in case of Germany, of flexible regulations of working time (Klinger \& Weber, 2019). In the countries of Southern Europe, a lower propensity to hoard labor is observed, which can be explained, in case of these countries, by a high share of temporary employees in total employment and by a significant percentage of self-employed.

Global crises result in difficulties on the European labor markets. During their lifespan, employment is decreasing on the labor markets in Europe, while unemployment is increasing. During the global crises - the 1998 Russian crisis and the 2008 financial crisis - employment was decreasing, but it was much less tailored to changes in production volume than expected. That resulted mainly from the fact that an adverse impact of decreased production was moderated by the reduced working time, new institutional solutions were introduced, while labor hoarding became a common strategy applied by enterprises during crises in Europe. The 1998 Russian crisis was a consequence of a significant and increasing internal debt of Russia, difficulties on the financial market and global oil price fall. Its effects were noticeable on all European labor markets economically related to Russia, however mainly in Central and Eastern Europe. The 2008 global crisis, in turn, translated into economic recession in the form of drop in employment and production, while due to a high degree of integration of the European countries in the world economy it was global, as its consequences reached the majority of EU labor markets. Any differences in the labor market adjustment to external shocks of the European labor market resulted from a disparity of national labor market institutions and applied labor market policies.

The aim of this article is to identify and evaluate the phenomenon of labor hoarding in the European Union countries in the years 1996-2016. The fundamental research question was formulated in the form of whether the phenomenon of labor hoarding in the European Union countries occurs at all and, if so, what is the direction of its changes. Literature studies and a review of the results of empirical research allowed us to put forward two research hypotheses:

H1: Labor hoarding phenomenon results more often from the lack of adjustments in the number of employees, than the number of hours worked to changes in the production volume

$\mathrm{H} 2$ : Reducing the phenomenon of labor hoarding in the European Union countries is associated with the negative effects of the Russian crisis of 1998 and the financial crisis of 2008.

The spatial scope of the empirical study covers the labor markets of the 28 European Union Member States. To identify the phenomenon of labor hoarding, quarterly data on real GDP and quarterly data on labor and hourly work productivity were used. The source of information was the Eurostat database. The empirical research period covered the years 1996-2016.

The article consists of the following parts. In the first theoretical part, the nature of the labor hoarding phenomenon and the ways of its measurement were determined. Reasons why companies decide to hoard labor were discussed. The second part characterized the information sources and research methods which were used to measure the phenomenon of 
labor hoarding in the European Union countries in the third part of the article. The last part discusses the results of the study and conclusions from the analysis.

\section{Labor hoarding - concept and measurements}

Labor hoarding at the end of the 1960s became part of mainstream economics, although this problem was present in the literature already in the interwar period (Stone, 1923; Clark, 1923). The solution to the procyclicality of productivity problem pointed out by Hultgren (1960), Kendrick (1961), and Fuchs (1968) permanently introduced the concept of a nonimmediate adaptation of employment to changes in production to the trends in main economic schools of thought. It was, however, contrary to the views expressed at that time, which indicated that short-term fluctuations in demand result in an increase or decrease in the workload with a relatively constant capital expenditure (Mitchell, 1922; Berridge, 1922). Empirical research gradually undermined the assumptions regarding the variability of costs related to the workload during the business cycle, which confirmed the procyclicality of labor productivity as a result. Thus, the theory of labor hoarding has become a suggestion to solve the problem of procyclical work productivity.

The concept of labor hoarding is based on the assumptions of the microeconomic theory of companies (Vella, 2018). Companies optimize their decisions over a long period of time, therefore decisions regarding employment costs, training and dismissals should also be optimized over a long period of time. Such an approach to the problem of employment costs, training and dismissals may lead to labor hoarding during short-term declines in production. Thus, a short-term reduction in production does not have to cause a reduction in the employment rate. Enterprises, when deciding to hoard labor, analyze the costs of employment, training and dismissal of employees as a fixed component of costs in the short-term. According to the theory of employee segmentation, the amount of these costs determines the willingness to hoard them. Employees with higher qualifications are more often retained in companies than unskilled workers with typical skills (Mangan, 1982; Pissarides, 1991). On the other hand, expenditure on recruitment and training costs incurred by enterprises employing fulltime employees is more likely to be returned (Bentolila et al., 2019; Chen et al., 2019). In the case of employees based on flexible employment forms, the costs of dismissals are lower (Booth \& Wood, 2008). A long-term policy of minimizing costs in companies may cause them to accept a reduction in labor productivity during the recession. This decision results from a comparison of the level of risk associated with the dismissal of trained employees in the conditions of a short-term drop in production, with the risk of their unavailability in a situation when production starts to grow. Hence the need to perceive employment costs as a constant factor of production in the short term, at least for selected groups of employees. In periods of short-term declines in production, companies may make employment cuts, which is usually associated with organizational change in these enterprises. Thus, lowering production is an incentive for enterprises to reduce unnecessary employment and improve work organization. The strength of employment response to changes in production volume also depends on institutional factors, including employment protection and wage flexibility.

Factors on company side, e.g. financial situation, expectations as to the duration of the 
economic slowdown may also determine the strength of this reaction. Enterprises with a strong market position tend to hoard labor more than those with lower market power (Mangan, 1982). Companies with a strong financial position will be more inclined to hoard their labor than enterprises in a disadvantageous situation (Bernanke \& Parkinson, 1991). Similarly, when enterprises expect improvement in the near future, they do not make decisions on dismissals. Irrespective of its motives, the delayed reaction of enterprises regarding adjustment of employment to production changes results in a decrease in labor productivity. Thus, short-term production changes in companies may lead to a situation in which production and labor productivity decrease simultaneously. Empirical research conducted in enterprises in various economies, among others by Lucas (1970), Mangan (1982), Pissarides (1991), Strzelecki et al. (2009), Dietz et al. (2010), Burda et al. (2019) proved that labor productivity grows faster when production reaches potential levels and decreases faster during reduced demand, and this applies to both individual enterprises, sectors and entire economies.

The phenomenon of labor hoarding can also be observed globally in the context of the relationship between fluctuations in production and labor productivity in the economy. Labor hoarding in economies occurs when, during short-term changes in production, employment does not change its level, or adjusts only slightly. The consequence of a simultaneous reduction in production and the occurrence of labor hoarding is a reduction in labor productivity. As a result, labor productivity decreases during the recession and increases during the recovery phase.

In the macroeconomic models of the labor market, labor hoarding is part of the demand for labor (Ehrenberg \& Smith, 2012; Vella, 2018). Taking into account the costs of employment, dismissal and training of employees leads to a milder adjustment of employment to changes in production, than would result from the models omitting the costs of labor hoarding. Nickell (1986) showed that in economies during periods of recovery the employment grows more slowly than the increase in production would suggest, similarly the employment decreases more slowly during periods of recession. The consequence of this is the observation regarding the procyclicality of work productivity. Models including costs of employment, training and dismissal of employees are modified by adjusting hourly work (Lucas, 1970; Ehrenberg \& Smith, 2012; Vella, 2018). Employment, in this case, reacts more slowly to decreasing production and this reaction is delayed (Ehrenberg \& Smith, 2012; Vella, 2018). A reasonable adjustment in the conditions of production fluctuation is the change in the number of hours worked, and not the change in employment size, which leads to a decrease in procyclicality of labor productivity.

Labor hoarding is the most important (Burnside et al., 1993), but not the only possible reason for the pro-cyclicality of labor productivity. In the literature on the subject, there are several competing explanations for this phenomenon; those given most often are technological progress, imperfect competition (Basu \& Fernald, 2001) and employee shifts within enterprises (Fay \& Mendoff, 1985).

Measuring the phenomenon of labor hoarding poses many difficulties, and it can take place at the level of enterprises as well as at the level of national economies. Identification of the phenomenon of labor hoarding in enterprises is carried out through surveys. This form is the best way to determine its level and direction of change (Pissarides, 1991; Burda et al. 
2019). However, this method has several limitations, including subjectivity of assessment, difficulty in determining the right frequency of surveys, and high costs. Governmental institutions, including European Commission Business and Consumer Surveys, the Russian Longitudinal Monitoring Survey or the Industrial Relations Research Unit at the University of Warwick conduct a series of surveys of companies, analyzing various aspects of their operations, including research on production and labor productivity. Data obtained in this way have, however, limited application, mainly due to the broad research objectives. In Poland, a cyclical survey of enterprises is conducted by the National Bank of Poland.

The second method of measuring the phenomenon of labor hoarding is the analysis of macroeconomic data on aggregate production and labor productivity. The basic assumption of the research concerns weak employment adjustment to changes in the production volume, which is the result of a strong positive relation between the real GDP growth dynamics and the labor productivity dynamics. Which results in the fact that in the economy in the periods of stagnation, the phenomenon of labor hoarding occurs, and during periods of economic recovery, there are only slight positive changes in employment. The advantages of this method are strong theoretical justification, high comparability of results and easy access to data. However, the use of macroeconomic data is associated with a significant level of generalization, which makes the interpretation of results difficult. It is often impossible to isolate factors related only to labor hoarding.

Combining both methods of measuring the phenomenon of labor hoarding seems justified (Pissarides, 1991; Strzelecki et al., 2009; Dietz et al., 2010), because comparing the results of both studies may result in the conclusions formulated on their basis being useful from the point of view of labor and personnel resources of enterprises.

In European Union countries, labor hoarding is a practice used in most countries. On the one hand, historically shaped mechanisms of employment protection (Boeri \& Garibaldi, 2005b; Ederveen \& Thissen, 2007; Pissarides, 1991; Stark, 1986), on the other, European institutional solutions (Dietz et al., 2010; Barth et al. 2017; Klinger \& Weber, 2019) are conducive to labor hoarding. In the countries of Central and Eastern Europe, the initial labor hoarding was explained by overstaffing of employment inherited from centrally planned economies (Strzelecki et al., 2009; Radlińska, 2018). Its current level depends on the solutions of labor market institutions, the strength of trade unions and regulation in the field of employment protection. Dietz et al. (2010) pointed out that changes in the system of job protection in German economy, including working time reduction and wage subsidies, or using working time accounts, significantly reduced the strength of employment adjustment to changes in production volume, which in turn led to the phenomenon of labor hoarding. In Italy, the current regulations on employment protection resulted in a decrease in labor productivity, which in turn resulted in only a slight adjustment of employment (Barth et al., 2017). The activities of trade unions in the Netherlands were directed at reducing the wage pressure, which, combined with the remuneration system launched after 2008, has led to an increase in the level of labor hoarding in recent years. On the other hand, labor market reforms in Spain resulted in an increase in temporary employment and, combined with restrictive protectionism of permanent employment, contributed to significant adjustments of employment to production volume (Cahuc et al., 2012). 


\section{Research methods and data sources}

The aim of this study is to identify and assess the phenomenon of labor hoarding in European Union countries in the years 1996-2016. The basic question which the study endeavored to answer, was formulated in the following form: whether the phenomenon of labor hoarding occurs in the European Union countries and, if so, what is the direction of its changes.

Identification and evaluation of the labor hoarding phenomenon was carried out using a method based on aggregated data; however, with full awareness of its limitations. The argument in favor of adopting such an approach was methodological simplicity. As a result, information on the size of real Gross Domestic Product (GDP) and on the level of labor productivity per person (LPP) and per hour (LPH) for all European Union countries was collected. Labor productivity per person (LPP) was defined as the ratio of production to the number of employees, while hourly productivity (LPH) was calculated as the production per hour of work (Baroniene \& Zirgutis, 2017; Lankauskiene, 2014). This approach to productivity allows us to fulfill the main objective of this study. The source of data on GDP and LPP and LPH was Eurostat. Data on GDP figures were expressed in prices of 2010, while LPP and LPH work productivity was indexed to $2010=100$. All measures used had a quarterly frequency.

The spatial scope of the empirical study covered the labor markets of 28 European Union member states. The temporal scope adopted is the period from the first quarter of 1996 to the fourth quarter of 2016. The exceptions were the countries of Croatia, Malta, Estonia and Poland for which the analyzed period was shortened due to lack of available data, and included, in the first three countries the first quarter of 2000 to the fourth quarter of 2016, and in the case of Poland, the first quarter of 2002 up to the 4th quarter of 2016.

The analysis was based on the assumption that labor hoarding arises in situations when the change in production volume does not change the number of employees or causes only a slight correction. Therefore, labor hoarding is always related either to a change in the effort that employees put into work (labor productivity per person - LPP) or with adjustment of working hours (labor productivity per hour - LPH). The conclusions from the analysis of the relation between the dynamics of change in real GDP and the growth in LPP and LPH were the basis for identifying the phenomenon of labor hoarding and assessing its changes.

The relationship between changes in real GDP and work productivity dynamics of LPP and LPH was estimated using the traditional Pearson's analysis of correlation coefficients and using their recursive modification with a shiftable time window of the size of twelve time periods. The classic Pearson correlation coefficients made it possible to determine the general relationship between the studied variables. Based on the values of the calculated Pearson correlation coefficients, the European Union countries were divided into groups. When the value of the coefficient reached values in the range $(0.9 ; 1.0>$ countries were classified as countries with pure labor hoarding. The coefficient values within the range $(0.7 ; 0.9>$ were characteristic for countries with high labor hoarding. The moderate level of labor hoarding involved countries in which the coefficient value was in the range $(0.5 ; 0.7>$. Low labor hoarding was achieved when the correlation coefficient value was in the range $(0.0 ; 0.5>$. No labor hoarding phenomenon was found when the coefficient value was 0 or was negative. This division has been made based on an analysis of results of the research conducted by Mangan (1982), Dietz et al. (2010), Moller (2010), Strzelecki et al. (2009). 
Recursive correlation coefficients, on the other hand, were used to conclude whether the analyzed relationship is stable over time and whether its strength is changing. The recursive modification of the correlation coefficient extends the interpretation possibilities of the correlation analysis by indicating the paths of convergence of variables. It involves estimating Pearson's correlation coefficient using the so-called sample rolling either by shifting the time window (Beck \& Grodzicki, 2014), or by expanding the sample (Adamowicz et al., 2009).

A planned correlation analysis between the dynamics of real GDP and the productivity dynamics of LPP and LPH requires proper preparation of series of studied variables. In the first step, the arrays were cleared of seasonal fluctuations using the Census X-12 ARIMA procedure. In the second step of preparations, the cyclical component was isolated from the time arrays of GDP dynamics and the labor productivity dynamics of LPP and LPH. To extract a cyclic component from the time arrays, various methods were used, e.g. PAT Phase-Average Trend method, polynomial deterministic trend, Beveridge-Nelsen decomposition, or structural time series model (Canova, 1998). The cyclic component can be extracted from the time arrays using filters extracting harmonic components with specific frequencies, e.g. Hodrick-Prescott, Baxter-King or Christiano-Fitzgerald filters (Christiano \& Fitzgerald, 1999; Hodrick \& Prescott, 1997; Nilsson \& Gyomai, 2011; Skrzypczyński, 2010). The isolation of the cyclic component from the dynamics of production and work productivity dynamics series was made using the Christiano-Fitzgerald filter. This filter minimizes or eliminates the limitations of other filters, e.g. requirements regarding length of time intervals or identification of mock cycles. Only such time arrays of the dynamics of the real GDP size and labor productivity of LPP and LPH were subject to further analyzes.

\section{Research results}

To determine and assess whether there was a phenomenon of labor hoarding in the European Union in the years 1996-2016, an analysis of traditional Pearson's linear correlation coefficients was carried out. The relationship between the real GDP growth rate and the labor productivity dynamics of LPP and LPH was examined, and the statistical significance of the estimates was checked. The relationship was considered statistically significant if the significance level of Pearson's correlation coefficient in both cases was lower than 0.05. Only in Spain the correlation coefficient between the dynamics of GDP and the dynamics of labor productivity turned out to be statistically insignificant $(\alpha=0.143)$. Therefore, 27 countries of the European Union were further examined.

The correlation of the real GDP growth rate and the growth in LPP and LPH employment productivity in all European Union countries in 1996-2016 was positive, which indicates the occurrence of labor hoarding, both in terms of the number of employees and the number of hours worked. Labor hoarding intensity was assessed taking into account the adopted assumptions. When the value of the Pearson correlation coefficient was greater than 0.9 , socalled pure labor hoarding was observed in the economy, while when the value of the coefficient was lower than 0.5 employment in the economy changed immediately with a change in production (low level of labor hoarding). 
Pearson's linear correlation coefficients between the change in real GDP and the change in LPH employment productivity for the analyzed period ranged from 0.5468 in Latvia to 0.9447 in Italy. The majority of European countries (22 out of 27) reached values higher than 0.7 , which may indicate a stability or slight change in the number of employees during periods of slowdown and growth (high labor hoarding). In eight European countries (Austria, Finland, Germany, Italy, Luxemburg, Malta, Sweden, the United Kingdom) the correlation between the real GDP growth and the LPP labor productivity growth was very strong - Pearson's correlation coefficients $>0.9$, countries characterized pure labor hoarding. In contrast, in five countries, i.e. Cyprus, Greece, Latvia, Portugal, Romania, correlation coefficients have reached the lowest $(0.5 \leq \mathrm{r} \leq 0.7)$, which may mean that enterprises in these countries to some extent use the employment adjustment mechanism in the business cycle, but the number of employees changes more slowly than production labor market characterized moderate labor hoarding.

The correlation of real GDP growth and LPH productivity growth has generally reached lower values than the correlation of real GDP growth and LPP labor productivity growth values from 0.2495 (Portugal) to 0.8464 (Luxembourg) (Table 1). Only in seven European countries (Germany, Ireland, Lithuania, Luxembourg, Malta, Slovakia, Great Britain) was it relatively high, which may indicate that the labor was hoarded and that the working hours in the business cycle were slightly adjusted - Pearson's correlation coefficients $>0.7$ (high labor hoarding). However, in most countries (19 out of 27), values were lower than 0.7 (moderate labor hoarding), which in turn may indicate significant adjustments in the number of hours worked during periods of slowdown and growth. In addition, in the economies of Cyprus, Estonia, Latvia, Portugal, only limited labor hoarding in the business cycle is observed, as there is a significant adjustment of employment in terms of working hours - countries characterized low labor hoarding.

Table 1. Correlation between GDP dynamics (dGDP) and labor productivity dynamics per employee (dLPP) and labor productivity dynamics per hour of work (dLPH) in the European Union countries in 1996-2016

\begin{tabular}{|l|c|c|}
\hline \multicolumn{1}{|c|}{ Country } & dGDP vs. dLPP & dGDP vs. dLPH \\
\hline European Union 28 & $0.9101^{\mathrm{a}}$ & $0.7638^{\mathrm{a}}$ \\
\hline Austria & $0.9417^{\mathrm{a}}($ pure LH) & $0.6634^{\mathrm{a}}$ \\
\hline Belgium & $0.8844^{\mathrm{a}}$ & b.d. \\
\hline Bulgaria & $0.7887^{\mathrm{a}}$ & $0.6081^{\mathrm{a}}$ \\
\hline Croatia ${ }^{*}$ & $0.7439^{\mathrm{a}}$ & $0.6983^{\mathrm{a}}$ \\
\hline Cyprus & $0.6222^{\mathrm{a}}$ & $0.2516^{\mathrm{b}}($ low LH) \\
\hline Czech Republic & $0.8771^{\mathrm{a}}$ & $0.5467^{\mathrm{a}}$ \\
\hline Denmark & $0.7886^{\mathrm{a}}$ & $0.6814^{\mathrm{a}}$ \\
\hline Estonia & $0.7699^{\mathrm{a}}$ & $0.3748^{\mathrm{b} *}($ low LH) \\
\hline Finaland & $0.9144^{\mathrm{a}}($ pure LH) & $0.4152^{\mathrm{a}}($ low LH) \\
\hline France & $0.8898^{\mathrm{a}}$ & $0.5552^{\mathrm{a}}$ \\
\hline Germany & $0.9346^{\mathrm{a}}($ pure LH) & $0.8230^{\mathrm{a}}$ \\
\hline
\end{tabular}


End of Table 1

\begin{tabular}{|l|c|c|}
\hline \multicolumn{1}{|c|}{ Country } & dGDP vs. dLPP & dGDP vs. dLPH \\
\hline Greece & $0.5808^{\mathrm{a}}$ & $0.4278^{\mathrm{a}}($ low LH) \\
\hline Hungary & $0.8747^{\mathrm{a}}$ & $0.6050^{\mathrm{a}}$ \\
\hline Ireland & $0.8641^{\mathrm{a}}$ & $0.8289^{\mathrm{a}}$ \\
\hline Italy & $0.9447^{\mathrm{a}}($ pure LH) & $0.6033^{\mathrm{a}}$ \\
\hline Latvia & $0.5468^{\mathrm{a}}$ & $0.3476^{\mathrm{b}}($ low LH$)$ \\
\hline Lithuania & $0.8871^{\mathrm{a}}$ & $0.8020^{\mathrm{a}}$ \\
\hline Luxembourg & $0.9320^{\mathrm{a}}($ pure LH) & $0.8464^{\mathrm{a}}$ \\
\hline Malta* & $0.9097^{\mathrm{a}}($ pure LH) & $0.7102^{\mathrm{a}}$ \\
\hline Netherlands & $0.8186^{\mathrm{a}}$ & $0.5854^{\mathrm{a}}$ \\
\hline Poland ${ }^{\star *}$ & $0.7025^{\mathrm{a}}$ & $0.5384^{\mathrm{a}}$ \\
\hline Portugal & $0.6749^{\mathrm{a}}$ & $0.2495^{\mathrm{b}}($ low LH$)$ \\
\hline Romania & $0.6438^{\mathrm{a}}$ & $0.5471^{\mathrm{a}}$ \\
\hline Slovakia & $0.8226^{\mathrm{a}}$ & $0.7444^{\mathrm{a}}$ \\
\hline Slovenia & $0.8965^{\mathrm{a}}$ & $0.6627^{\mathrm{a}}$ \\
\hline Sweden & $0.9041^{\mathrm{a}}\left(\right.$ pure LH$^{\mathrm{a}}$ & $0.6864^{\mathrm{a}}$ \\
\hline United Kingdom & $0.9201^{\mathrm{a}}\left(\right.$ pure LH$^{\mathrm{a}}$ & $0.8234^{\mathrm{a}}$ \\
\hline
\end{tabular}

where: $0.9<\mathrm{r}_{\text {dPKB vs. dLPP }} \leq 1.0 ; 0.9<\mathrm{r}_{\text {dPKB vs. } \mathrm{dLPH}}<1.0-$ pure labor hoarding; $0.7<\mathrm{r}_{\mathrm{dPKB} \text { vs. } \mathrm{dLPP}} \leq$ 0.9; $0.7<\mathrm{r} \mathrm{r}_{\text {dPKB vs. dLPH }}<0.9$ - high labor hoarding; $0.5<\mathrm{r}_{\mathrm{dPKB} \text { vs. } \mathrm{dLPP}} \leq 0.7 ; 0.5<\mathrm{r} \mathrm{r}_{\mathrm{dPKB}}$ vs. dLPH $<$ 0.7 - moderate labor hoarding; $0<\mathrm{r}_{\text {dPKB vs. dLPP }} \leq 0.5 ; 0<\mathrm{r} \mathrm{r}_{\text {dPKB vs. dLPH }}<0.5$ - low labor hoarding; $-1.0 \leq \mathrm{r}_{\mathrm{dPKB}}$ vs. dLPP $\leq 0.0 ;-1.0<\mathrm{r}_{\mathrm{dPKB}}$ vs. $\mathrm{dLPH}$ $<0-$ no labor hoarding.

Note: ${ }^{\mathrm{a}}$ indicates level of significance $a<0.001,{ }^{\mathrm{b}}$ indicates level of significance $a<0.05$

* indicates data from 2000-2016, ** indicates data from 2002-2016.

The correlation coefficients calculated for all European Union countries indicate a strong pro-cyclical changes in the productivity of employment (LPP) $(r=0.9101)$ - pure labor hoarding and quite strong pro-cyclical changes in hourly productivity LPH $(r=0.7638)$. The observed pro-cyclicality of changes in LPP employment productivity and pro-cyclical changes in LPH hourly productivity gave rise to the conclusion that the phenomenon of labor hoarding in the analyzed period in the European Union countries was occurring. It applies more strongly to non-immediate changes in the number of employees than to nonimmediate changes in the number of hours worked.

The institutional determinants of the labor market in individual countries are different and affect the mechanisms of adjustment in a different way. Western European countries (United Nations [UN], 2018) were characterized by the highest pro-cyclical nature of changes in labor productivity LPP and pro-cyclical changes in the hourly productivity LPH. Strong protectionism of Western European countries aimed at job protection, incentives for flexible forms of employment, pay subsidies and active attitude of trade unions (Blanchard \& Landier 2002; Moller, 2010; Klinger \& Weber, 2019) are the factors that influenced the limited adjustment of employment to changes in real production. Consequently, this led to a significant labor hoarding. In these countries the number of employees and the number of working hours in the economic slowdown phase remain constant or decrease more slowly than production. 
On the other hand, the countries of Southern Europe (UN, 2018) were characterized by the strongest adjustment of employment to changes in volume, both in the context of LPP employment productivity and LPH productivity. In this group of countries, the phenomenon of labor hoarding was a minor mechanism for adjustment, especially with regard to working hours. The system of flexible working time, the seasonal nature of employment in these countries resulted in the adjustment of employment to changes in production volume being almost immediate. The correlation coefficients of the real GDP growth rate and changes in LPH productivity point to a weak relationship. In Portugal and Cyprus this coefficient did not exceed 0.3 , which indicates almost an immediate adjustment of working hours to changes in production volume. The countries of Northern Europe (UN, 2018) were characterized by a relatively high level of labor hoarding, not much lower than the level in Western European countries. The relationship between the dynamics of real production and the productivity dynamics of LPP and LPH observed in the countries of Central and Eastern Europe is interesting. The cultural roots and historical conditions common to these countries have made the phenomenon of labor hoarding important, although trends have changed as a result of the passage of time and differences in the level of socio-economic development. Labor hoarding is particularly noticeable in the Visegrad Group countries, and less in the other Baltic and Balkan countries - this applies to both the number of employees and worked hours.

Analysis and assessment of real GDP growth rate correlation coefficients and LPP employment productivity dynamics as well as LPH productivity allowed for confirmation of the first hypothesis. In the European Union countries, labor hoarding is more often due to the lack of adjustment in the number of employees to changes in production volume. All European Union countries are characterized by poor employment adjustment measured by the number of employees and a stronger adjustment of the number of hours worked. All the conclusions formulated above were made on the basis of assumptions that labor hoarding can be an explanation of the procyclicality of labor productivity fluctuations.

The next step of the study was analyzing the stability of fluctuations in GDP and changes in LPP employment productivity and hourly LPH productivity in the European Union countries in the period 1996-2016 and attempting to assess the changes in labor hoarding related to the negative effects of the Russian crisis of 1998 and the global crisis of 2008. Moving correlation coefficients with a running window of twelve quarters were used to study covariability and stability.

The analysis of moving-window correlations for three-year periods shows that pro-cyclical productivity was characterized by high variability in time, and this concerned both the LPP productivity and hourly LPH productivity. Employment and hourly productivity followed the rate of change in production volume, with changes in hourly productivity reacting more strongly. The lowest changeability in the dynamics of employment and hourly productivity was found in the economies of Luxembourg, Italy and the United Kingdom, and a relatively weak reaction in the number of employees was observed in Germany and Austria. The situation results from the maturity of these economies, as each of them has developed labor market institutions that introduced mechanisms to protect jobs and gave broad powers to enterprises in the area of shaping flexible forms of employment, changes in the number of working hours and salary. The activity of trade unions is very important 
for the functioning of the labor market (an example of the labor market in Italy). The most volatile dynamics of employment and hourly productivity are characteristic of the countries of Southern Europe, excluding Italy and Malta. This can be explained by the large share of services sector in these economies and their seasonal nature. The countries of Central and Eastern Europe were characterized by relatively high volatility, which in turn may result from the economic transformation of these countries, the transition from a centrally planned economy to a market economy. The results of the rolling correlation coefficients estimated for the dynamics of GDP and the labor productivity dynamics of LPP and LPH for selected European Union countries are presented in Figure 1.

In general, in the European Union countries, during the analyzed time, two periods of economic slowdown were observed, i.e. 1997-1998 and 2008-2009, and during these periods in most European countries a decrease in labor productivity growth was observed, both in LPP and hourly LPH. These slowdowns are direct or delayed consequences of global crises: the Russian crisis of 1998 and the global crisis of 2008.

In a period when a large or long-lasting economic slowdown was observed in a country (appearing during a period of external shocks), large fluctuations in the LPP productivity of employment and hourly LPH were also observed. The Russian crisis of 1998 resulted in a significant reduction in procyclicality of labor productivity. Although the direct economic links between the Russian economy and European countries were not high, the effects of the crisis were felt in all European countries. In all European Union countries, a adjustment of employment to GDP changes was observed, which indicates a reduction in the phenomenon of labor hoarding; what is more, this applies both to the number of employees and the number of working hours. However, the largest adjustments in this period can be noticed on the labor markets of Central and Eastern Europe, in particular in the countries of the Visegrad Group and former Soviet republics. In the early 1990s, these countries were characterized by a significant number of economic links with Russia. In addition, the strength of these adjustments was increased by the relatively small market experience of these countries and the labor market policies used.

However, the global crisis of 2008 is more related to the hourly adjustment of work, and therefore the phenomenon of labor hoarding is observed, but it mainly concerns the number of employees. Due to the high degree of integration of countries in the global economy, it was global in nature, and covered most of the European Union countries with its consequences. During the crisis of 2008, the labor markets of Southern European countries - Italy, Greece, Portugal and Ireland responded by adjusting their wages, preventing excessive unemployment. In the initial phase, the countries of Central and Eastern Europe reacted with a strong increase in unemployment, especially Latvia, Estonia and Lithuania, which, due to wage adjustments, started to decrease before the second wave of the crisis. In other labor markets of the EU, the consequences of the 2008 crisis were not as significant. Such a change in the adjustment mechanism may be caused by the experience of individual countries. Indeed, the manner and strength of employment adjustments to changes in production volumes may be influenced by the state policy in the field of job protection - an example of Germany, Great Britain and Italy, as well as the specificity of the economy, as was the case in Luxembourg and Ireland. 

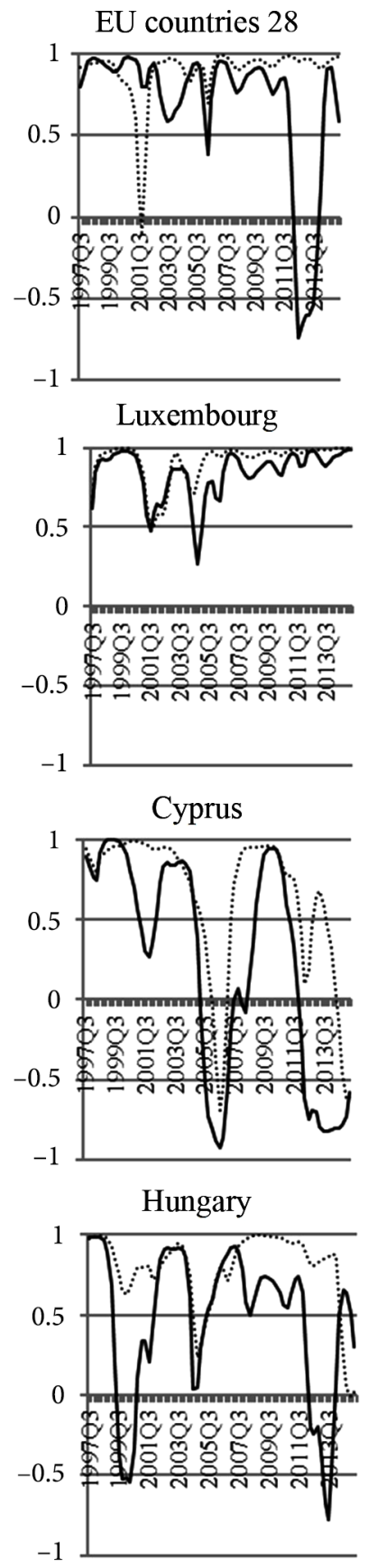

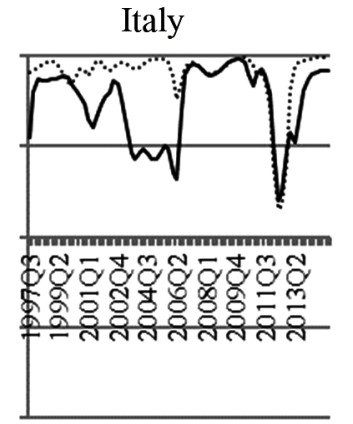

UK

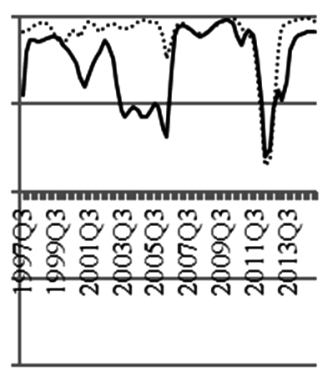

Portugal

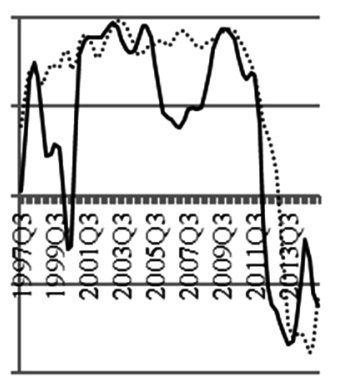

Latvia

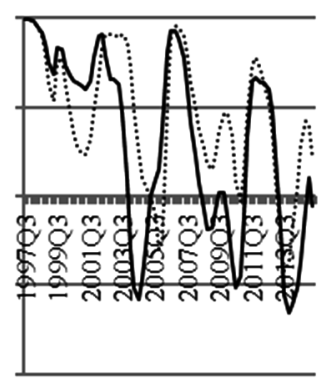

Germany

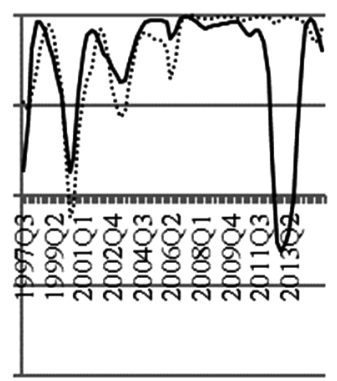

The Netherlands

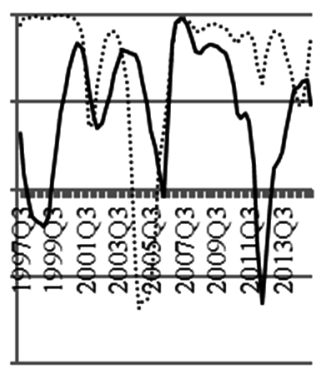

Croatia

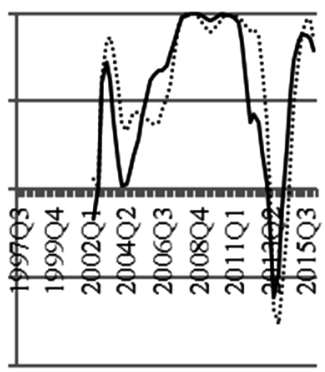

Bulgaria

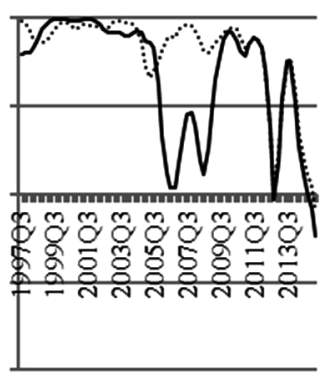

$r$ rol dPKB vs. dLPP

rol dPKB vs. dLPH

Figure 1. Pro-cyclicity of work productivity (rolling correlations) 
The analysis and evaluation of research results allows us to conclude that as a result of the global crises of 1998 and 2008, the phenomenon of labor hoarding was reduced. In the first case, there was a decrease in labor hoarding both in the context of the number of employees and the number of hours worked and concerned a selected group of countries - Central and Eastern Europe countries. The second was mainly related to the reduction of the number of hours worked.

\section{Conclusions}

Labor hoarding is one of the possibilities of adjusting employment to changes in production volume in a short period of time. Companies during economic slowdown decide to retain employees when the costs of their dismissal, re-admission and training are higher than the costs of their maintenance during periods of production decline. This practice applies to employees with unique qualifications, employed full-time. Labor hoarding can be observed in companies in a good financial condition and depends on the expectations of enterprises as to the duration of the slowdown. At present, companies, apart from adjusting the number of employees, have the opportunity to adjust working hours and pay rates. However, the strength of adjustment depends on the functioning of labor market institutions and labor market policies used. The state policy in the area of protectionism of employment and shortening of working hours, subsidies to pay rate and tax preferences are tools that effectively strengthen labor hoarding. Demographic situation and the growing demand for goods and services are conducive to labor hoarding as well. Therefore, during periods of slowdown nowadays, no reaction can be observed on the side of the number of employees and a strong or moderate response on the side of working hours.

In macroeconomic terms, the decisions of companies about labor hoarding directly affect labor productivity. In the economies in which enterprises maintain their jobs, the procyclical nature of labor productivity is observed. Although it should be mentioned that the pro-cyclical nature of labor productivity may result from other reasons than labor hoarding, including technical progress and increased competition. Nevertheless, the higher the pro-cyclicality of LPP and LPH work productivity, the more labor hoarding is noticeable.

The phenomenon of labor hoarding is a characteristic feature of most of the world's economies. European countries as a result of significant protection of employment are obliged to maintain employment at an unchanged level, despite declining production. On the other hand, labor market reforms aimed at reducing the number of working hours, promoting flexible forms of employment have resulted in the possibility of using hourly work adjustments. All in all, this means that the phenomenon of labor hoarding in European countries is observed, however it is more noticeable in terms of the number of employees than of working hours. The conducted empirical study showed that in the countries of the European Union, labor hoarding is a practice used in periods of short-term changes in production, although its extent is varied. On the basis of the analysis of GDP dynamics, LPP labor productivity dynamics and LPH productivity, it can be concluded that in the European Union there is a phenomenon of labor hoarding during short-term changes in production, however, at present more often work time adjustments are used during economic changes. 
The analysis of changes in GDP and labor productivity (LPP and LPH) in EU countries in 1996-2016 clearly shows that EU countries hoard labor. In Austria, Finland, Germany, Italy, Luxembourg, Malta, Sweden and Great Britain the so-called pure labor hoarding can be observed. In other EU countries, the change in the number of employees during the economic recession is also small. On the other hand, it can be noted that EU countries use a reduction in the number of hours worked during the economic slowdown. Immediate adjustments in the number of hours worked are observed in the labor markets of Cyprus, Estonia, Finland, Greece, Latvia and Portugal. Therefore, it can be assumed that the phenomenon of labor hoarding results more often from lack of adjustments in the number of employees, than in the number of hours worked to changes in the volume of production.

The results of the study on labor hoarding stability in EU economies showed that labor hoarding (employment numbers and number of hours worked) changed over the period under consideration during global economic fluctuations. The first adjustment in the volume of employment and the number of working hours was observed during the Russian crisis of 1998, in particular on the labor markets of Central and Eastern Europe. In Slovakia, Lithuania, Estonia, Hungary and Latvia there was a significant reduction in labor productivity (both the number of employees and the number of hours worked were reduced). During the global crisis of 2008, the response of EU labor markets was slightly different. Hoarding of the number of employees was observed in all countries - the response of employment to changes in the volume of production was small. However, adjusting working hours to changes in production volume was of great importance during this period. This approach to labor hoarding was most clearly seen on labor markets in Germany, Austria, Luxembourg and Italy.

The conducted labor hoarding analysis enabled to define the level and trends of changes in labor hoarding in European economies, unambiguously indicating the hourly flexibility of employment. This situation under the conditions of continuously decreasing level of unemployment results in the fact that the response of employment is slowly losing its cyclical nature. That is why, apart from the observation and measurement of labor hoarding, it seems important to select supply and demand factors affecting enterprises' decisions on labor hoarding, which would constitute a valuable completion of previous analysis.

\section{References}

Adamowicz, E., Dudek, S., Puchucki, D., \& Walczyk, K. (2009). Synchronizacja cyklu koniunkturalnego polskiej gospodarki z krajami strefy euro w kontekście struktury tych gospodarek. In Raport na temat pełnego uczestnictwa Rzeczypospolitej Polskiej w trzecim etapie Unii Gospodarczej i Walutowej (pp. 8-224). Narodowy Bank Polski.

Arntz, M., Gregory, T., \& Zierahn, U. (2016). The risk of automation for jobs in OECD countries: A comparative analysis (OECD Social, Employment and Migration Working Papers No. 189). OECD Publishing. https://doi.org/10.1787/5jlz9h56dvq7-en

Baroniene, L., \& Zirgutis, V. (2017). Cybersecurity faces: counterfactual impact evaluation of measure "Procesas LT" in enterprises of the IT sector. Journal of Security and Sustainability Issues, 6(3), 445-457. https://doi.org/10.9770/jssi.2017.6.3(10)

Barth, E., Davis, J., Freeman, R., \& Kerr, S. P. (2017). Weathering the great recession: Variation in employment responses, by establishments and countries. RSF: The Russell Sage Foundation Journal of the Social Sciences, 3(3), 50-69. https://doi.org/10.7758/rsf.2017.3.3.03 
Basu, S., \& Fernald, J. (2001). Why is productivity procyclical? Why do we care? In Ch. R. Hulten, E. R. Dean, \& M. J. Harper (Eds.), Developments in productivity analysis. University of Chicago Press. https://doi.org/10.3386/w7940

Beck, K., \& Grodzicki, M. (2014). Konwergencja realna i synchronizacja cykli koniunkturalnych w Unii Europejskiej. Wymiar strukturalny. Wydawnictwo Scholar. https://doi.org/10.7172/1733-9758.2014.17.6

Bentolila, S., Dolado, J. J., \& Jimeno, J. F. (2019). Dual labour markets revisited (Working Paper No. 7479). Center for Economic Studies and Ifo Institute (CESifo), Munich. https://doi.org/10.1093/acrefore/9780190625979.013.502

Bentolila, S., \& Dolado, J. J. (1994). Labour flexibility and wages: lessons from Spain. Economic Policy, 9(18), 53-99. https://doi.org/10.2307/1344458

Bernanke, B. S., \& Parkinson, M. L. (1991). Procyclical labor productivity and competing theories of the business cycle: Some evidence from interwar U.S. manufacturing industries. Journal of Political Economy, 99(3), 439-459. https://doi.org/10.1086/261761

Berridge, W. A. (1922). Employment and the business cycle. The Review of Economics and Statistics, 4(1), 12-51. https://doi.org/10.2307/1924610

Biddle, J. E. (2015). The genealogy of the labor hoarding concept. In L. Fiorito, S. Scheall, \& C. E. Suprinyak (Eds.), A research annual: Vol. 33. Research in the history of economic thought and methodology (pp. 125-161). Emerald Group Publishing Limited. https://doi.org/10.1108/S0743-415420150000033013

Blanchard, O. (2004). Designing labor market institutions. Memo. MIT, NBER.

Blanchard, O., \& Landier, A. (2002). The pervese effects of partial labor market reform: Fixed duration contracts in France. Economic Journal, 112(480), 214-244. https://doi.org/10.1111/1468-0297.00047

Boeri, T. (2011). Institutional reforms and dualism in European labor markets. Handbook of Labor Economics, 4(Part B), 1173-1236. https://doi.org/10.1016/S0169-7218(11)02411-7

Boeri, T., \& Garibaldi, P. (2005a). Two tier reforms of employment protection: A honeymoon effect?. Economic Journal, 117(521), 357-385. https://doi.org/10.1111/j.1468-0297.2007.02060.x

Boeri, T., \& Garibaldi, P. (2005b). Are labour markets in the new member states sufficiently flexible for EMU? Journal of Banking \& Finance, 30(5), 1393-1407. https://doi.org/10.1016/j.jbankfin.2005.07.005

Booth, A. L., \& Wood, M. (2008). Back-to-front down under? Part-time/full-time wage differentials in Australia. Industrial Relations: A Journal of Economy and Society, 47(1), 114-135. https://doi.org/10.1111/j.1468-232X.2008.00507.x

Burda, M. C., Genadek, K. R., \& Hamermesh, D. S. (2019). Unemployment and effort at work. Economica. https://doi.org/10.1111/ecca.12324

Burnside, C., Eichenbaum, M., \& Rebelo, S. (1993). Labor harding and business cycle. The Journal of Political Economy, 101(2), 245-273. https://doi.org/10.1086/261875

Cahuc, P., Charlot, O., \& Malherbet, F. (2012). Explaining the spread of temporary jobs and its impact on labor turnover (IZA Discussion Paper 6365). Forschungsinstitut zur Zukunft der Arbeit. Institute for the Study of Labor (IZA).

Canova, F. (1998). Detrending and business cycle facts. Journal of Monetary Economics, 41(3), 475-512. https://doi.org/10.1016/S0304-3932(98)00006-3

Card, D. E., Cardoso, A. R., Heining, J., \& Kline, P. (2016). Firms and labor market inequality: Evidence and some theory (IAB-Discussion Paper 19/2016). Institut fürArbeitsmarkt- und Berufsforschung (IAB), Nürnberg. https://doi.org/10.3386/w22850

Cassell, C., Nadin, S., Gray, M., \& Clegg, Ch. (2002). Exploring human resource management practices in small and medium sized enterprises. Personnel Review, 31(6), 671-692.

https://doi.org/10.1108/00483480210445962 
Chen, K. J., Lai, C. C., \& Lai, T. W. (2019). Business cycle fluctuations with the division of permanent and temporary employment. Economic Inquiry, 57(4), 2082-2109. https://doi.org/10.1111/ecin.12814

Christiano, L. J., \& Fitzgerald, T. J. (1999). The band pass filter. NBER. https://doi.org/10.3386/w7257

Clark, J. M. (1923). Studies in the economics of overhead cost. University of Chicago Press.

Dawson, Ch., Veliziotis, M., \& Hopkins, B. (2017). Temporary employment, job satisfaction and subjective well-being. Economic and Industrial Democracy, 38(1), 69-98. https://doi.org/10.1177/0143831X14559781

Day, I., \& Rodgers, J. (2015). The premium for part-time work in Australia. Australian Journal of Labour Economics, 18(3), 281.

Dietz, M., Stops, M., \& Walwei, U. (2010). Safeguarding jobs through labor hoarding in Germany. Applied Economics Quarterly, 61, 125-166.

Ederveen, S., \& Thissen, L. (2007). Can labour market institutions explain high unemployment rates in the new EU member states? Empirica, 34(4), 299-317. https://doi.org/10.1007/s10663-006-9030-z

Ehrenberg, R. G., \& Smith, R. S. (2012). Modern labor economics. Theory and public policy (11 ed.). Pearson Education.

Fay, J. A., \& Mendoff, J. L. (1985). Labor and output over the business cycle: Some direct evidence. The American Review, 75(4), 638-655.

Frey, C. B., \& Osborne, M. A. (2017). The future of employment: How susceptible are jobs to computerisation?. Technological Forecasting and Social Change, 114, 254-280. https://doi.org/10.1016/j.techfore.2016.08.019

Fuchs, V. R. (1968). Front matter, The Service Economy. In V. R. Fuchs (Ed.), The service economy. National Bureau of Economic Research.

Gałecka-Burdziak, E. (2017). Randomness or stock-flow: which mechanizm describes labour market matching in Poland? Baltic Journal of Economics, 17(2), 119-135. https://doi.org/10.1080/1406099X.2017.1344481

Hart, R. A. (2019). Labor productivity during the Great Depression in UK manufacturing (IZA Discussion Papers No. 12379). Institute of Labor Economics (IZA).

Hodrick, R. J., \& Prescott, E. C. (1997). Postwar U.S. business cycles: An empirical investigation. Journal of Money, Credit and Banking, 29(1), 1-16. https://doi.org/10.2307/2953682

Hultgren, T. (1960). Changes in labor cost during cycles in production and business. NBER.

Jiménez-Rodríguez, R., \& Russo, G. (2012). Aggregate employment dynamics and (partial) labour market reforms. Bulletin of Economic Research, 64(3), 430-448. https://doi.org/10.1111/j.1467-8586.2011.00396.x

Kendrick, J. W. (1961). Productivity trends in the United States. Princeton University Press.

Klinger, S., \& Weber, E. (2019). GDP-Employment decoupling and the slow-down of productivity growth in Germany (IAB-Discussion Paper No. 12/2019). Institute for Employment Research (IAB).

Lankauskiene, T. (2014). Accounting productivity In the sectors of economy: methodological aspects, Entrepreneurship and sustainability Issues, 2(2), 98-106. https://doi.org/10.9770/jesi.2014.2.2(5)

Lopes de Melo, R. (2018). Firm wage differentials and labor market sorting: Reconciling theory and evidence. Journal of Political Economy, 126(1), 313-346. https://doi.org/10.1086/695505

Lucas, R. E. (1970). Capacity, overtime, and empirical production functions. The American Economic Review, 60(2), 23-27.

Mangan, J. (1982). The determinants of labour hoarding in Australian manufacturing. University of Wollongong.

Mitchell, W. C. (1922). The crisis of 1920 and the problem of controlling business cycles. The American Economic Review, 12(1), 20-32. 
Moller, J. (2010). The German labor market response in the world recession - de-mystifying a miracle. Zeitschrift für Arbeitsmarkt Forschung, 41(4), 325-336. https://doi.org/10.1007/s12651-009-0026-6

Nickell, S. J. (1986). Dynamic models of labour demand. Handbook of Labor Economics, 1, 473-522. https://doi.org/10.1016/S1573-4463(86)01012-X

Nilsson, R., \& Gyomai, G. (2011). Cycle extraction: A comparison of the phase-average trend method, the Hodrick-Prescott and Christiano-Fitzgerald filters (OECD Statistics Working Papers 2011/04). OECD Publishing. https://doi.org/10.1787/5kg9srt7f8g0-en

Nitoi, M., \& Pochea, M. M. (2016). Productivity clustering and growth in Central and Eastern Europe. Baltic Journal of Economics, 16(2), 132-151. https://doi.org/10.1080/1406099X.2016.1189267

Olkiewicz, M. (2015). Knowledge management as a determinant of innovation in enterprises. In Proceedings of the 9th International Management Conference Management and Innovation for Competitive Advantage (pp. 399-409), Bucharest, Romania.

Pissarides, Ch. A. (1991). Labor hoarding in industrial countries: Concept and measurment. Eurostat, ISTAT, OECD.

Quiggin, J. (2011). What have we learned from the global financial crisis? The Australian Economic Review, 44(4), 355-365. https://doi.org/10.1111/j.1467-8462.2011.00661.x

Radlińska, K. (2018). Mechanism of employment adjustment to short-term changes in production. Examples of Polish enterprises. Przedsiębiorczość i Zarządzanie, 19(4), 257-268.

Skrzypczyński, P. (2010). Metody spektralne w analizie cyklu koniunkturalnego gospodarki polskiej. Materiaty i Studia. Narodowy Bank Polski.

Stark, D. (1986). Rethinking internal labor markets: New insights from a comparative perspective. American Sociological Review, 51(4), 492-504. https://doi.org/10.2307/2095583

Stone, N. I. (1923). Methods of stabilizing production of textiles, clothing, and novelties. In Committee of President's Conference on Unemployment, and Special Staff of the National Bureau (Ed.), Business cycles and unemployment. (pp. 118-135). NBER.

Strzelecki, P., Wyszyński, R., \& Saczuk, K. (2009). Zjawisko chomikowania pracy w polskich przedsiębiorstwach po okresie transformacji. Bank i Kredyt, 40(6), 77-104.

Tressel, T., \& Scarpetta, S. (2004). Boosting productivity via innovation and adoption of new technologies: any role for labor market institutions? The World Bank. https://doi.org/10.1596/1813-9450-3273

United Nations. 2018. Standard country or area codes for statistical use (M49). https://unstats.un.org/unsd/methodology/m49/

Vella, M. (2018). Employment and labour hoarding: a production function approach. Journal of Economics, Finance and Administrative Science, 23(46), 230-246. https://doi.org/10.1108/JEFAS-07-2017-0079

Wilthagen, T., \& Tros, F. (2004). The concept of 'flexicurity': A new approach to regulating employment and labour markets. European Review of Labour and Research, 10(2), 166-187. https://doi.org/10.1177/102425890401000204 